\title{
Dynamism of Instructional Aids on Teaching Physical Education Among Secondary School in Kogi State, Nigeria
}

\author{
Ajadi Memunat Tunrayo ${ }^{*}$, Falaye Elijah Kayode², Adebayo \\ Babatunde Samson ${ }^{3}$ \\ ${ }_{1 * 23}$ Department of Human Kinetics Education, University of Ilorin, Ilorin, Kwara State, \\ Nigeria
}

\begin{abstract}
Article History:
Received: 9 March 2021

Accepted: 25 April 2021

Published: 26 April 2021
\end{abstract}

Keywords:

Dynamism; Instructional Aids; Physical Education; Behavioural Benefits; Cognitive Benefits

\begin{abstract}
This study examined dynamism of instructional aids on teaching of physical education among secondary school in Kogi State, Nigeria. Descriptive research design of survey type was used. The population for this study consist all Secondary School students within the study area. Purposive and random sampling techniques were used to select 394 respondents. Researcherstructured questionnaire was used for data collection. The instrument was validated by three lectures in the department of Human Kinetics Education, University of Ilorin and tested for reliability. A correlation coefficient of 0.85 was obtained. The administration of the instrument was done by the researchers. The data collected were analysed using Pearson Product Moment Correlation (PPMC) and percentage count. The results revealed that, there was a significant relationship between behavioural benefits and cognitive benefits of instructional aids on teaching of Physical Education among Secondary Schools. The study concluded that uses of instructional aids are significant to quality teaching of physical education in schools. The study recommends that effective uses of instructional aids plays a significant role in teaching and learning of physical education in schools which also enhance the behavioural and cognitive benefits of the students.
\end{abstract}

\section{How To Cite:}

Tunrayo, A. M, Kayode, F. E, \& Samson, A. B. (2021). Dynamism of Instructional Aids on Teaching Physical Education Among Secondary School in Kogi State, Nigeria. Indonesian Journal of Sport Management, 1(1), 41-49. https://doi.org/10.31949/ijsm.v1i1.931

Corresponding author: Ajadi Memunat Tunrayo, Department of Human Kinetics Education, University of Ilorin, Ilorin, Kwara State, Nigeria

Email: sampayoo2014@gmail.com and mtajadi2014@gmail.com 


\section{INTRODUCTION}

Effective teaching beckons on teachers approach in terms of teaching methods and medium of impacting knowledge. Current trend in teaching-learning process stressed the importance of the use of instructional materials which aid both the teacher and the learners in discharging their duties in and after classroom situation (Akinbi, Fatoki \& Lawal, 2019).

Instructional aid learning resources associated with objects, person or other aspects of the environment which can be used to impact or help in any learning activity. Apart from the chalkboard and textbooks which are often available for teachers to use, instructional aid teaching materials that aid or are capable of complementing the teacher's effort in teaching-learning process (Onyilagba and Nnajiofor, 2016). Furthermore, the use of appropriate instructional materials in the classroom during the teaching-learning process will often make the learners to attain employable skill development through hands-on experiences especially in practical classes (Perello-Marin, Ribes-Giner \& Diaz, 2018). Igiri and Effiong (2015). Submitted that the use of instructional aids significant impact on teaching and learning of students in the following ways; the use of teaching aids often makes learning real and permanent, it promotes retention and influences the academic achievement of students. The influence of instructional aids on teaching and learning of Physical Education in schools could be grouped into behavioural, cognitive and emotional benefits.

Similarly, Onyilagba and Nnajiofor (2016) stressed that instructional aids are diverse which include the printed and audio-visual materials, visual instructional aids for teaching of Physical Education are materials that are feasible, real, touchable and helpful to the teaching and learning of skills. These teaching aids include the following; the fluid, court, gymnasium, 3-dimensional camera, goal post, ball, racket, canvas, net, instructor. Audio materials needed for the teaching and learning of Physical and Health Education in schools could include recorded materials and live radio transmission on the other hand, audio-visual materials for teaching and learning Physical and Health Education at primary and junior secondary schools include television, talking board, computer and projector. Instructional aids could be tool locally made or imported that often use to facilitate learning (Ajadi, Adebayo \& Falaye, 2018). Instructional aids also play an important role in teaching-learning process as they enhance the memory level of the learners.

In the recent time, education has gone beyond oral ways of teaching and learning for successful pedagogy to take place, the teacher has to use instructional aids to make teaching and learning process interesting especially in practical classes. Oyekan (2018) advances the fact that visual materials are Effective in conveying ideas and content more easily than verbal descriptions for visual learners and are important learning enhancements in the classroom. According to Oyekan, course content enriched with charts, diagrams, photographs, visual presentation, videos and maps is more easily absorted by pupils. However, as a means of facilitating teaching and learning visual materials are not just a means of transforming knowledge but the most important thing is the extension of both the teacher and chalkboard.

Instructional aids play a key role in successful teaching of physical education, it gives the students a new platform on which to focus their attention after 
successive speaker and when done correctly can really capture and utilize this attention to motivate student's behaviour. In like manner, teachers need interactive multimedia in their teaching situations o illuminate contents to aid student's achievement of instructional objectives (Ofuani, 2014). Some of the reasons why instructional material should be employed in teaching and learning of physical education include: instructional aids assist teachers to transmit the knowledge in an impressive way giving diversity to classroom teaching and making learning more effective, interactive media also ensures that students acquire larger knowledge and ensures that the gained knowledge is relatively permanent, instructional resources make learning more meaningful and satisfying to learners; when interactive media are used in teaching and learning situations, it appeals to the learners sensory organs thereby motivating the learners.

Instructional materials helps the teachers in preparing and presenting the learning contents in a more organized and systematic way teaching aids also helps to adjust learning climate to promote acceptance of an idea by the students, it also provides for time control of display of most media in conformity with instruction design and in so doing, reduces redundant and repeated pieces of course contents and saves time meant for writing on the blackboard. (Bhaliya, 2015). Classroom interaction is also very important as these interactions are between teachers and students which may also include discussion, debates in practical class that play a role and collaborating in the learning process.

Abdulraheem (2014) stated that instructional aids often develop students' idea through the creation of events and objectives which will improve the students continuity through effective use of instructional materials that will facilitates, stimulated and aids students to take active interest in the subject under study. It improves the emotional instruction of students by providing them with the required knowledge. It helps the students to understand the working model introduced by the teacher. The students captures the true picture of what is taught by the teacher in presenting subject content and motion pictures, instructional aids plays an efficient role by making sure that the students captures the main points or the subject matter (Iyunade, 2014). The instructional aid serves as an instrument for impacting positively to the students to survive and choose their choice of career in tertiary institution. Instructional aids also help students to attain to his high level effectively through the use of appropriate instructional objectives and other teaching resources students who manifest a lot of inconsistence in their behaviours are those who are not able to attain enough use in the aspect of their affective, cognitive and psychomotor domain (Abdulraheem \& Oluwagbohunmi, 2015).

The use of instructional aids usually took to the account the background of the students in the Physical Education classes of secondary schools level. However, effective instruction enables students to acquire specified skills, knowledge and attitudes. In order to ensure an effective teaching-learning process, it is important for the teachers to be thoroughly acquainted with the teaching aids and services available for the teachers to be thoroughly acquainted with the teaching aids and services available for him/her. Teachers have a great impact on the effective application of teaching aids or instructional material; this is because the teachers need to understand the sequential presentation of the instructional gadgets so as to 
suit the interest of the learners and its appropriateness with the instructional task (Adeoluwa, 2018).

The failure of educational system to provide adequate and appropriate teaching - learning aids in order to improve academic performance of students is of great concern to government, educational institutions and other concern citizens. It is in view of this that this study examined effectiveness of instructional aids on teaching of physical and education in schools in Kogi state, Nigeria.

Education process is changing on daily basis, it has moved away from the era of oral teaching to the use of instructional aids. Technology provides various ways of designing the best instructional aids that suit the subject matter in order to facilitate teaching-learning process. Physical education is a science subject that cannot be taught through oral means alone but with the use of concrete objects especially during the practical class, if proper acquisition and execution of skills are required. The researchers observed that most of the physical education teachers in the study area find it difficult to use modernized instructional aids to teach the subject and this often hindered the performance of secondary school students especially in both terminal exam and external exams like National Examination Council (NECO).

The evaluation of students' performance in Physical Education is necessary to ascertain the effectiveness of the teacher as regard using instructional aids to teach or to impart knowledge. Also, some of these teachers are also found of using primitive idea to teach due to the fact that they are not computer literate. Hence, this study therefore examined the effectiveness of instructional aids on teaching of Physical Education among schools in Kogi State, Nigeria.

\section{METHOD}

Descriptive research design of survey typed was employed for this study. This research design was considered appropriate for the study because of the relative characteristics of the respondents with a view to determine the relationship between effective use of instructional aids and teaching and learning of Physical Education. The population for this study comprised all senior secondary school students (S.S III) in 14 schools in Okene local government Area with approximately $(8,698)$ students (Kogi State Teaching Service Commission, 2020). The sampling technique for this study consist of random, purposive and propionate sampling technique. Purposively SS III students were sampled and proportionate sampled was used to select 30\% from each school sampled. In school A 107 that represent $30 \%$ were sampled, School B 73 respondents were sampled, school C 73 respondents were sampled, school D 104 respondents were sampled and in school E, 37 respondents were sampled. In all 394 respondents were sampled for this study. A researcher structured questionnaire titled "Effectiveness of Instructional aids on teaching and learning of Physical Education among secondary schools" (EIATLPESS).

The instrument was validated and tested for reliability using Pearson Product Moment Correlation (PPMC) Correlation Coefficient of 85 was obtained. The administration of the questionnaire was done by the researchers and two (2) trained research assistants. The data collected were analysis using descriptive statistics of percentage to answer the research question while inferential statistics 
of Pearson Product Moment Correlation (PPMC) was used to test the postulated hypotheses set for the study at 0.05 alpha level.

\section{RESULT AND DISCUSSION}

Research Question One: Will the behavioural benefits of instructional aids have influence teaching and learning of Physical Education among secondary school students in Okene Local Government?

Table 1. Response of instructional materials in teaching and learning of physical education

\begin{tabular}{|c|c|c|c|c|c|c|c|c|}
\hline S/N & ITEMS & SA & A & FR & D & SD & UR & RT \\
\hline 1. & $\begin{array}{l}\text { The use of } \\
\text { Instructional } \\
\text { materials in } \\
\text { teaching and } \\
\text { learning } \\
\text { Physical Education } \\
\text { modifies students' } \\
\text { actions in the } \\
\text { society }\end{array}$ & $\begin{array}{c}89 \\
(22.6 \%)\end{array}$ & $\begin{array}{c}189 \\
(48 \%)\end{array}$ & $\begin{array}{c}278 \\
(70.6 \%)\end{array}$ & $\begin{array}{c}46 \\
(11.7 \%)\end{array}$ & $\begin{array}{c}70 \\
(17.7 \%)\end{array}$ & $\begin{array}{c}116 \\
(29.4 \%)\end{array}$ & 394 \\
\hline 2. & $\begin{array}{l}\text { Social interaction } \\
\text { among students is } \\
\text { encourages } \\
\text { through the use of } \\
\text { instructional } \\
\text { materials in } \\
\text { teaching and } \\
\text { learning of } \\
\text { Physical Education. }\end{array}$ & $\begin{array}{c}110 \\
(27.9 \%)\end{array}$ & $\begin{array}{c}226 \\
(57.4 \%)\end{array}$ & $\begin{array}{c}336 \\
(85.3 \%)\end{array}$ & $\begin{array}{c}36 \\
(9.1 \%)\end{array}$ & $\begin{array}{c}22 \\
(5.6 \%)\end{array}$ & $\begin{array}{c}58 \\
(14.7 \%)\end{array}$ & 394 \\
\hline 3. & $\begin{array}{l}\text { Bad attitudes } \\
\text { among students } \\
\text { are corrected } \\
\text { through the use of } \\
\text { instructional } \\
\text { materials in } \\
\text { teaching and } \\
\text { learning } \\
\text { Physical Education. }\end{array}$ & $\begin{array}{c}108 \\
(27.4 \%)\end{array}$ & $\begin{array}{c}198 \\
(50.3 \%)\end{array}$ & $\begin{array}{c}312 \\
(79.2 \%)\end{array}$ & $\begin{array}{c}29 \\
(7.4 \%)\end{array}$ & $\begin{array}{c}53 \\
(13.4 \%)\end{array}$ & $\begin{array}{c}82 \\
(20.8 \%)\end{array}$ & 394 \\
\hline 4. & $\begin{array}{l}\text { Morals are } \\
\text { inculcated into } \\
\text { students when } \\
\text { they pass through } \\
\text { the teaching and } \\
\text { learning of } \\
\text { Physical Education. }\end{array}$ & $\begin{array}{c}87 \\
(22.1 \%)\end{array}$ & $\begin{array}{c}189 \\
(48 \%)\end{array}$ & $\begin{array}{c}276 \\
(70.1 \%)\end{array}$ & $\begin{array}{c}78 \\
(19.8 \%)\end{array}$ & $\begin{array}{c}40 \\
(10.1 \%)\end{array}$ & $\begin{array}{c}118 \\
(29.9 \%)\end{array}$ & 394 \\
\hline
\end{tabular}

The analysis of items one in table one reveals that $278(70.6 \%)$ of the respondents agreed that use of instructional materials in teaching and learning of Physical Education modifies students' actions in the society. Also, 296 (75.1\%) of the respondents agreed that social interaction among students is encourages through the use of Instructional aids in teaching and learning of Physical Education. Moreover, 306 (77.7\%) of the respondents agreed that bad attitudes among students are corrected through the use of instructional maids in teaching and 
learning of Physical Education. The table one also reveals that $276(70.1 \%)$ of the respondents agreed that morals are inculcated into student when they pass through the teaching and learning of Physical Education. The analysis of overall results of the items presented in table one shows that 1156 (73.3\%) of the respondents responded favourably that there is relationship between the behavioural benefits of instructional maids and teaching-learning of Physical Education among secondary school students in Okene Local Government, while $420(26.7 \%)$ of the respondents responded unfavourably that there is no relationship between the behavioural benefits of instructional maids and teaching-learning of Physical Education.

Table 2. Respondents agreed that Physical Education students recall vividly lessons taught using

\begin{tabular}{|c|c|c|c|c|c|c|c|c|}
\hline$S / N$ & ITEMS & SA & A & FR & D & SD & UR & RT \\
\hline 1. & \begin{tabular}{lr}
\multicolumn{2}{l}{ Physical Education } \\
students recall \\
vividly lessons \\
taught using \\
instructional \\
materials.
\end{tabular} & $\begin{array}{l}98 \\
(24.9 \%)\end{array}$ & $\begin{array}{l}190 \\
(48.2 \%)\end{array}$ & $\begin{array}{l}288 \\
(73.1 \%)\end{array}$ & $\begin{array}{l}68 \\
(17.3 \%)\end{array}$ & $\begin{array}{l}38 \\
(9.6 \%)\end{array}$ & $\begin{array}{l}106 \\
(26.9 \%)\end{array}$ & 394 \\
\hline 2. & $\begin{array}{l}\text { Physical Education } \\
\text { taught with the use } \\
\text { of instructional } \\
\text { materials promote } \\
\text { mental alertness. }\end{array}$ & $\begin{array}{l}85 \\
(21.6 \%)\end{array}$ & $\begin{array}{l}204 \\
(51.8 \%)\end{array}$ & $\begin{array}{l}289 \\
(73.4 \%)\end{array}$ & $\begin{array}{l}74 \\
(18.8 \%)\end{array}$ & $\begin{array}{l}22 \\
(7.8 \%)\end{array}$ & $\begin{array}{l}58 \\
(26.6 \%)\end{array}$ & 394 \\
\hline 3. & $\begin{array}{l}\text { The use of } \\
\text { instructional } \\
\text { materials in } \\
\text { teaching and } \\
\text { learning of } \\
\text { Physical Education } \\
\text { improve students' } \\
\text { performance in } \\
\text { other subjects. }\end{array}$ & $\begin{array}{l}110 \\
(27.9 \%)\end{array}$ & $\begin{array}{l}226 \\
(57.4 \%)\end{array}$ & $\begin{array}{l}336 \\
(85.3 \%)\end{array}$ & $\begin{array}{l}36 \\
(9.1 \%)\end{array}$ & $\begin{array}{l}22 \\
(5.6 \%)\end{array}$ & $\begin{array}{l}58 \\
(14.7 \%)\end{array}$ & 394 \\
\hline 4. & $\begin{array}{l}\text { There is distortion } \\
\text { of information } \\
\text { since teaching and } \\
\text { learning of } \\
\text { Physical Education } \\
\text { comes inform of } \\
\text { play. }\end{array}$ & $\begin{array}{l}84 \\
(21.3 \%)\end{array}$ & $\begin{array}{l}288 \\
(57.9 \%)\end{array}$ & $\begin{array}{l}312 \\
(79.2 \%)\end{array}$ & $\begin{array}{l}29 \\
(7.4 \%)\end{array}$ & $\begin{array}{l}53 \\
(13.4 \%)\end{array}$ & $\begin{array}{l}82 \\
(20.8 \%)\end{array}$ & 394 \\
\hline
\end{tabular}

The analysis of items two in table two reveals that 288 (73.1\%) of the respondents agreed that Physical Education students recall vividly lessons taught using instructional maids. Also, 289 (73.4\%) of the respondents agreed that Physical Education taught with the use of instructional maids promote mental alertness. Furthermore, 336 (85.3\%) of the respondents agreed that the use of instructional maids in teaching and learning of Physical Education improve students' performance in other subjects. The table two also reveals that 312 (79.2\%) of the respondents agreed that there is distortion of information since teaching and learning of Physical Education comes inform of play. The analysis of overall results of the items presented in table seven shows that $1225(77.7 \%)$ of the respondents responded favourably that there is relationship between the cognitive benefits of 
instructional aids and teaching-learning of Physical Education among secondary school students in Okene Local Government, while 351 (22.3\%) of the respondents responded unfavourably that there is relationship between the cognitive benefits of instructional materials and teaching-learning of Physical Education among secondary school students in Okene Local Government, Kogi State.

Table 3. Correlation analysis of the behavioural benefits of instructional maids and teachinglearning of Physical Education among secondary school students

\begin{tabular}{cccccccc}
\hline Variables & N & Mean & SD & Df & $\begin{array}{c}\text { Cal. } \\
\text { r-value }\end{array}$ & Sig. & Decision \\
\hline $\begin{array}{c}\text { Behavioural benefits } \\
\text { Teaching and learning of } \\
\text { Physical Education }\end{array}$ & 394 & 19.32 & 12.447 & 392 & .346 & .000 & $\begin{array}{c}\text { Ho } \\
\text { Rejected }\end{array}$ \\
\hline
\end{tabular}

Table 3 revealed that the calculated $r$-value of 0346 and significant value of 0.000 computed at 0.05 alpha level. Since the calculated $r$-value is greater than the p-value, hence, the null hypothesis is hereby not accepted. This means that there was a significant relationship between the behavioural benefits of instructional maids and teaching-learning of Physical Education among secondary students in Okene Local Government, Kogi State.

Table 4. Correlation analysis of the cognitive benefits of instructional maids and teaching-learning of Physical Education among secondary school students

\begin{tabular}{cccccccc}
\hline Variables & $\mathrm{N}$ & Mean & SD & Df & $\begin{array}{c}\text { Cal. } \\
\text { r-value }\end{array}$ & Sig. & Decision \\
\hline Cognitive benefits & 394 & 12.13 & 4.335 & 392 & .433 & .000 & $\begin{array}{c}\mathrm{H}_{0} \\
\text { Rejected }\end{array}$ \\
$\begin{array}{c}\text { Teaching and learning of } \\
\text { Physical Education }\end{array}$ & 394 & 21.22 & 3.221 & & & & \\
\hline
\end{tabular}

Table 4 revealed that the calculated $r$-value of 0.443 and significant value of 0.000 computed at 0.05 alpha level. Since the calculated $r$-value is greater than the p-value, hence, the null hypothesis is hereby not accepted. This means that there was a significant relationship between the cognitive benefits of instructional maids and teaching-learning of Physical Education among secondary school students in Okene Local Government, Kogi State.

The Pearsons Product Moment Coefficient result for hypothesis one as shown in table three necessitated for the rejection of null hypothesis. This means that there was a significant relationship between the behavioural benefits derived from the use of instructional aids and teaching-learning of Physical Education among secondary school students in Okene Local Government. This finding is in line with the submission of Abdulraheem (2014) stated that instructional material help students attain to his high level effective development through the use of appropriate instructional objectives and use of material. Students who manifest a lot of inconsistencies in their behaviours are those who are not able to attain enough development in their aspect of the affective domain. Oyekan (2018) also stated that instructional materials took into account the background of the student in the 
Physical and Health Education in the secondary schools. It adequately modifies students by proving instructional media together with sound institution management techniques.

The Pearson Product Moment Coefficient result for hypothesis two as shown in table four necessitated for the rejection of null hypothesis. This means that there was a significant relationship between cognitive benefits derived from the use of instructional maids and teaching-learning of Physical Education among secondary school students in Okene Local Government. This finding is in line with the submission of Bhaliya (2015) that instructional aids stimulate students desire to learn. Equally assist the student learning process by making assimilation and memorization materials easy and help to hold attention as well as longer retention of information.

Similarly, Onyilagba and Nnajkofor (2016) affirmed that it improve the emotional instruct of students by providing them with the required knowledge. Improve students from understanding the working model introduced by the teacher. The student captures the true picture of what is taught by the teacher. In presenting subject content and motion pictures, instructional materials plays an efficient role by making sure students captures the main points or the subject matter.

\section{CONCLUSION}

The use of instructional aids is significant to quality teaching and learning of Physical Education in schools. This implies that behavioural benefits and cognitive benefits are fundamental to effective teaching and learning of Physical Education in Secondary Schools. This study therefore recommends that government should assist in the provision of expensive instructional materials needed in schools to teach Physical Education.

\section{ACKNOWLEDGEMENT}

Thank you to all those who have supported the completion of this research, especially to secondary school students.

\section{REFERENCES}

Abdulraheem, B.0 (2014) Improvision of Instructional materials for teaching and learning in Secondary Schools as predict of high academic standard. Nigeria Journal of Social Studies, 17(1) 131-143.

Abdulraheem, B.O, \& Oluwagbohunmi M.F (2015) Pre-service teachers' problems of Improvisation of instructional material in social studies in Ekiti State. Journal of Education and Practices 6, (3) 160-169.

Adeoluwa, O.V (2018) Innovative Classroom Practice and Sustainable Development in Education: The way forward, keynote address presented at the $8^{\text {th }}$ Annual Nationa Conference of the School Education, Adeyemi College of Education, Ondo State.

Ajadi, M.T, Adebayo, B.S \& Falaye, E.K (2018) Utilization of ICT for Effective Teaching and Learning of Physical Education in Secondary Schools in Kwara State. Ekiti State University Journal of Education 8 (2) 137-143. 
Akinbi, Y.A, FAtoki, O, R \& Lawal, B.O (2019) utilization and Significance of Instructional Materials for an Effective teaching - learning process and Sustainable Development in Basic Education. Nigerian Journal of Educational Foundations. 18 (2), 15-23.

Bhaliya, R.S (2015) Classroom Interaction retrieved from www.slideshare.net on $12^{\text {th }}$ may, 2018

Igiri, C, E \& Effiong O, E (2015). Impact of Instructional Materials in Teaching and Learning of Biology in Senior Secondary Schools in Yakurr Local Government Area. International Journal of Humanities and Social Sciences. 4, 62-72.

Iyunade, O.T (2014). Availability and utilization of Instructional Material in selected Andra gogical setting in Ogun State, Nigeria. International Journal of Humanities and Social Science 4 (4) 268-277.

Ofuani, F.N (2014) Learning environment for literacy development. Journal of Reading Association of Nigeria (RAN) 15 (2) 301-307.

Onyilagba, J.C \& Nnajiofor, F.N (2016) Comparative Study of the Impact of Instructional Materials and Technology on Traditional and Distance Education Systems. International Journal for Innovation Education and Research. 4(2) 71-78.

Oyekan, S.O (2018) Implementation of Innovative classroom practices for Sustainable Development in Education. A lead paper presented at the $8^{\text {th }}$ Annual National Conference of the school of Education, Adeyemi College Education, Ondo State.

Perello-Marin, M.R, Ribes-Giner \& Diaz, O, P. (2018) Enhancing Education for Sustainable Development in Environment University Programme.

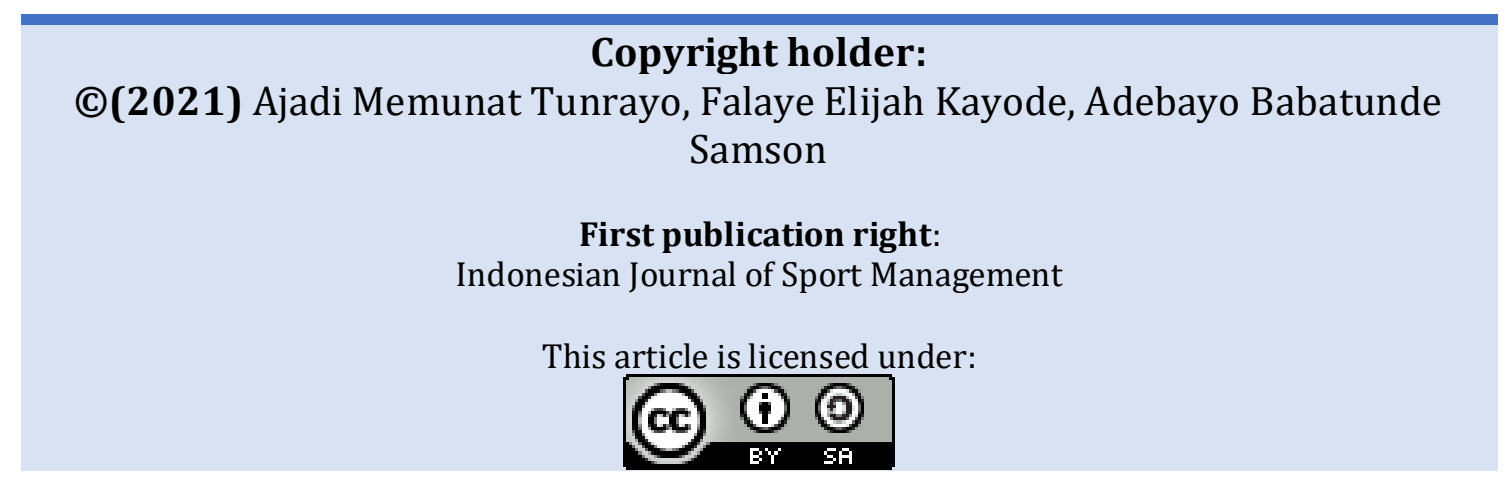

